\title{
The Relationship Between Job Stress and Head Nurses Job Performance
}

Ghada Mosaad Mohamed El-Ghabbour, Fathya AbdelRazek Afify, Magda Taha Kamal El-Din Fahmy, Neamat Mohamed El-Sayed, Assistant Lecturer of Nursing Administration, Faculty of Nursing, Port-Said University, Lecturer of Nursing Administration, Faculty of Nursing, Suez Canal University. Professor of Psychiatric Medicine, Suez Canal University, Faculty of Medicine, Professor of Nursing Administration, Faculty of Nursing, Damanhur University,

\begin{abstract}
Background : Nursing is the largest healthcare profession. It is critical to the quality of patient care and the success of any healthcare delivery system since nurses serve as the principal caregivers in hospitals and other institutional care settings. Their work requires a high degree of emotional labor. As Nurses are expected to display, emotions that convey caring, understanding, and compassion toward patients while they regulate their own feelings. This Study Aimed: To assess the relationship between job stress and head nurses job performance. Methods: An analytical correlation study, the population of the study included 30 head nurses' working in all units at four hospitals affiliated to the Ministry of Health namely: Port- Said general hospital ( $\mathrm{n}=11$ units), Port- Fouad general hospital ( $\mathrm{n}=10$ units), El- Naser hospital ( $\mathrm{n}=4$ units), and El-Zohoor hospital ( $n=5$ units).Data were collected using two structured questionnaires; the first one is the stress-rating questionnaire, the second tool is the job performance questionnaire. Results: The results of the present study revealed that the majority of head nurses have high job stress level and poor job performance. Whereas there was no significant correlation between job performance and head nurses level of job stress. Conclusion: Based on the results of the present study, it can be concluded that the head nurses working in all patient care units at four hospitals had experienced high level of job stress and poor job performance. To reduce the negative outcomes of stress, it was recommended that implement stress management-training program in hospitalss for all nurses in order to improve staff performance.
\end{abstract}

Key Words: job stress, job performance, head nurses 


\section{INTRODUCTION}

Job stress is a new or old concept, introduced first by Selye at the beginning of the twentieth century and recently, it became one of the most important contemporary issues in applied research. The factors that lead to stress, its consequences and the necessary strategies to deal with distress outcomes exist in the life of every individual, within the family relations, at work and in any career, in any organization, all over the world (Al-Khasawneh \& Futa, 2013). Nursing job specifically encounters several kinds of stress that will not be found in other non-health sectors; they are working in a unique environment; full of noise, pollution, and they are susceptible to infections. It is a job that seeks patience, high mental and physical capabilities (Ugur et al., 2007). Moreover, head nurse is the first line nurse manager who has full time responsibility for administration of nursing unit and hence the managerial success of this nursing unit (Herbett et al., 2000). There are three main areas that constitute her role. They are; patient care management to ensure that patient total needs are met, staff management to utilize, guide, evaluate, and correct staff nurses in their nursing practice, in addition to unit management to ensure its smooth running to fulfill hospital goals (Hermina et al., 2003).

Stress is something ordinary, unavoidable fact in anyone life, caused by many factors either at work, or with the family at home, or at the external environment (Jarinto, 2011). The outcome of job stress exceeds productivity and quality of employees performance, its psychological influence inverts into bad lifestyle habits like smoking, over eating, drinking alcohol and leads to serious chronic diseases like hypertension and heart diseases (Owolabi1 et al., 2012). Moreover, it could lead in nursing job to clinical errors, negligence in a way that could be critical to the safety of patients (Wilton, 2011).

In this regard, Kreitner and Kincki (2010) presented four levels of stressors in the individual life: Individual level, which consists of role conflict, role ambiguity and role overload, boredom and routine under load jobs. Group levels: lack of cohesiveness inside the same group and groups' conflict. Organizational level: culture, organizational structure, technology, organizational change and the style of leadership. Non-work (Extra organizational) stressors: family, age, quality of life and economic factors. Rue and Byars (2007) added that working conditions with unpleasant organizational climate, the physical environment: light, temperature, noise and the rigidity of rules and regulations are job stressors. Salami et al. (2010) considered instability in the 
organizations' policies, rules and procedures due to continuous change, strategic alliances or acquisitions can be major stressors in any organization.

Stress consequences: Stress has its outcomes on the organization and the employees too; on the organizational side. Casio (2013) considered job stress and its consequences as major factors in increasing organizations' cost; as a result of absenteeism, performance, work stoppage, turnovers, accidents and strikes. In addition, it has a direct impact on the communication process inside the organization and the interaction with customers, in maintaining good and balanced relationships with peers and leaders (Jaramillo et al., 2011). The primary goal of every organization (small or big) is achieving and maintaining effective performance of its employees. (Aslam, 2011). Staff performance is recognized as an integral component in providing quality of health care within the hospital setting (Larrabee et al., 2004). Furthermore, performance evaluation serves a number of purposes; the most common include determining salary increases, making promotion decisions, providing employee feedback and training, making termination decisions, and conducting personnel research (Robbins \& judge, 2009).

Employees tend to perform best when they are experiencing low or moderate degree of stress. However, too much stress leads to falling in employees' performance when the amount of stress moves from moderate to high (Certo, 2003). In this regard, few studies have investigated the relationship between occupational stress and job performance on international level. Tuten \& Neidermeyer (2004) have found that " high job stress leads to high job performance", while Leveck \& Jones (1996), and Westman \& Eden (1996) found that "high job stress leads to low job performance", in addition to "people with moderate stress perform better than do those with high or low levels of stress (Steers and Black, 1994). However, few known studies covered this relationship at the national level in Egypt such as; "high job stress leads to high job performance" (ElSayed, 1997 and Shash, 2006), while El-Sherif (1998) found that these nurses are exposed to high level of stress that leads to their burnout. Furthermore, performance management of human resources provides the sound basis of evaluating and developing employee performance in order to get enhanced organizational success. Thus, the current study investigated the relationship between occupational stress and job performance among head nurses at Port-Said hospitals.

\section{AIM OF STUDY:}

Study was conducted to investigate the relationship between job stress and head nurses job performance.

The study aimed to obtain the following objectives: 
1. Determine the job stress level among head nurses.

2. Identify the most important dimensions that lead to stress for head nurses working at the Hospital.

3. Determine job performance level among head nurses.

4. To find out the relationship between job stresses and job performance among head nurses.

\section{SUBJECTS AND METHODS:}

The design for this study used an analytical correlational research design, it was conducted at four hospitals affiliated to the Ministry of Health (Port-Said general hospital, Port-Fouad general hospital, El-Zohoor, and El-Naser hospital). The study sample consisted of all head nurses working in inpatient units in the above mentioned setting (30 H.N), with inclusion criterion at least was one year experience. Data of this study were achieved through using three different tools:

Tool I: Stress rating questionnaires: Consists of two parts, Part I: includes personal and occupational characteristics for studied head nurses. Part $\Pi$ : Stress-rating questionnaires, was developed by the researcher guided by the nursing stress scale Grat-Toft \&Anderson (1981); Abdelrazek (2000); Sash (2006); and El-Shaer (2009). Its purpose to determine the level of job stress among head nurses and consisted of 112 statements categorized under 11 subscales namely: work environment stressors (15 items), workload stressors (16 items), work duties and responsibilities stressors (9 items), lack of organization support stressors (6 items), head nurses' capabilities for work demand stressors (10 items),work and education stressors (10 items),relations between physician and head nurses' stressors (11 items),staff nurses stressors (8 items),patients suffering and death stressors (10 items), material stressors (8 items), and work satisfaction, achievement and promotion stressors (9 items). These items were rated on a 5 point Likert scale ranging from 1, 2, 3, 4, and 5 for the responses never stressful, rarely stressful, occasional stressful, almost stressful, and extremely stressful, respectively (EI-Shaer, 2009). For each domain of factors, the scores of the items were summed-up and the total divided by the number of the items, giving a score for the part. These scores were converted into a percent score. The scoring system was categorized as follows: high stress level $=$ more than $75 \%$ of response, moderate stress level $=$ from $65 \%$ to $75 \%$ of response, and low stress level = below $65 \%$ of response (El-Sayed, 1997).

Tool П: Job performance Evaluation check list "observational sheet: it was developed by the researcher guided by the UOCHR (2005); Hamouda (2006); and 
SOMOADOP (2010). This sheet was used to evaluate head nurses' performance in their work setting. The observational sheet consisted of 100 items categorized into four main dimensions namely: work hours and habits dimensions: included work hours compliance/attendance (11 items), work dimensions: included quality and quantity of work (12 items), Patients service (9 items), job knowledge and skills (4 items), workload management (5 items), and safety / health (9 items), leadership / supervisory dimensions: included leadership / delegation (8 items), training / orientation (5 items), and attitude and mood (11 items), employments dimension: included adaptability and cooperation (5 items), communications (11 items), interpersonal skills (5 items), and initiatives (5 items).

An observational job performance sheet items were measured on 5- point Likert scale ranging from $5,4,3,2$, and 1 , for the responses always, often, sometimes, rarely, and never, respectively for the all positive statements, and this scoring was reversed from 1 to 5 for negative statements no $(2,3,6,7,17,64,64,65,66,67,68,69,70,71,72,73$, 74, 87, 88, 89, 90). For each area, items scores were summed up and the total divided by the number of the items, giving a mean score for the job performance. To estimate the cut off point, the median was calculated (338.50) and divided by the total score of job performance evaluation scale (500) giving a result of (0.677), these score were converted into a percentage score (cut off point $68 \%$ ). The subject was considered to have "good performance" if the percentage score was $68 \%$ or more and "poor performance if less than $68 \%$.

For the questionnaires' validity it was revised by a number of academic staff working at several universities in Egypt, Their notes were taken into consideration in reformulating the questions. Cronbach's Coefficient Alpha was used to examine the internal consistency of the questions, the results of the study variables were as follows: Stress Rating questionnaires (0.96), Job Performance questionnaires (0.76). It is obvious that all the variables had more than (0.65) internal consistency and according to Sekaran (2004) and Crosby et al., (2006) the study's questionnaire was reliable.

\section{RESULTS:}

Table (1): shows the personal characteristics of head nurses in the study setting. It was found that the highest percentage of studied head nurses' age ranged between 30 to less than 40 years at three hospitals Port-Foaud (PFH), El-Zohoor (EZH), and El-Naser $(\mathrm{ENH})(40 \%, 40 \%, \& 75 \%$ respectively), whereas in Port-Said hospital (PSH), the highest percentages of head nurses age was under 30 years $(45.5 \%)$. In addition, the 
highest percentage $(81.8 \%, 90 \%, 60 \%$, and $75 \%)$ of head nurses in all hospitals (PSH, $\mathrm{PFH}, \mathrm{ENH}$, and EZH respectively) were married. Regarding educational level, the highest percentage $(90 \%)$ of head nurses who had secondary nursing school diploma were found in PFH compared to bachelors of science in nursing in EZH (80\%), followed by $45.5 \%$ in PSH had secondary nursing school diploma whereas all educational degrees were equally distributed in ENH.

Table (2): shows occupational characteristics of head nurses in the study setting. It was found that, the highest percentage of head nurses in PSH (27.2\%) were working in emergency and accident unit followed by $30.0 \%$ of them in PFH were working in medical unit, whereas in EZH (40.0\%) and ENH (50.0\%) of them were working in critical care unit. Concerning level of experience in nursing field, the highest percentages of head nurses in PSH and ENH had experience ranging from five to less than 15 years $(45.5 \%$ and $100 \%$ respectively), whereas the highest percentages $(40.0 \%)$ in PFH had experience ranging from 25 to less than 35 years and in EZH (60.0\%) had under five years of experience in nursing field. Besides, the highest percentage of head nurses $(66.7 \%)$ in all hospitals mentioned that the level of experience in the current position was less than 10 years of experience.

Table (3): clarifies head nurses' job stress levels. It was found that, the highest percentage of head nurses had high work stress levels in items related to work environment stressors, lack of organization support stressors, work and education stressors, staff nurses stressors, material stressors, work satisfaction, and achievement and promotion stressors $(50 \%, 66.6 \%, 56.6 \%, 66.6 \%, 66.6 \%$ and $66.6 \%$ respectively). Regarding the total scores of job stress this table also indicated that the majority of head nurses had high job stress level (60\%)

Table (4): demonstrates head nurses' job performance levels in the study sample. It is evident that the highest percentage of head nurses had poor job performance in relation to total score $(70.0 \%, 80.0 \%, 100 \%$, and $73.3 \%$ respectively). Regarding the total scores of job performance this table also indicated that the number of head nurses with poor job performance constituted $83.3 \%$.

Table (5): shows the correlations matrix between head nurses' job stress and job performance scores in the study sample. It was found that there was no statistically significant correlation between job performance and head nurses' level of job stress. 
Table (1): Personal characteristics of head nurses in the study setting $(n=30)$.

\begin{tabular}{|c|c|c|c|c|c|c|c|c|c|c|c|}
\hline \multirow{3}{*}{\multicolumn{2}{|c|}{ Personal characteristics }} & \multicolumn{10}{|c|}{ Hospitals Name } \\
\hline & & \multicolumn{2}{|c|}{$\begin{array}{c}\text { Port-Said } \\
\text { (PSH) } \\
n=11\end{array}$} & \multicolumn{2}{|c|}{$\begin{array}{c}\text { Port-Foaud } \\
\text { (PFH) } \\
n=10 \\
\end{array}$} & \multicolumn{2}{|c|}{$\begin{array}{c}\text { El-Zohor } \\
(\text { EZH) } \\
n=5\end{array}$} & \multicolumn{2}{|c|}{$\begin{array}{c}\text { El-Naser } \\
(\text { ENH) } \\
n=4\end{array}$} & \multicolumn{2}{|c|}{$\begin{array}{l}\text { Total } \\
n=30\end{array}$} \\
\hline & & $\mathbf{N}$ & $\%$ & $\mathbf{N}$ & $\%$ & $\mathbf{N}$ & $\%$ & $\mathbf{N}$ & $\%$ & $\mathbf{N}$ & $\%$ \\
\hline \multirow[t]{4}{*}{ Age (years) } & $<30$ & 5 & 45.5 & 0 & 0.0 & 2 & 40.0 & 1 & 25.0 & 8 & 26.7 \\
\hline & $30-$ & 3 & 27.3 & 4 & 40.0 & 2 & 40.0 & 3 & 75.0 & 12 & 40.0 \\
\hline & $40-$ & 2 & 18.2 & 2 & 20.0 & 0 & 0.0 & 0 & 0.0 & 4 & 13.3 \\
\hline & $50+$ & 1 & 9.1 & 4 & 40.0 & 1 & 20.0 & 0 & 0.0 & 6 & 20.0 \\
\hline \multicolumn{2}{|l|}{$\begin{array}{l}\text { Min }-\max \\
\text { Mean } \pm \text { SD }\end{array}$} & \multicolumn{2}{|c|}{$\begin{array}{c}26-56 \\
43.82 \pm 11.1 \\
3\end{array}$} & \multicolumn{2}{|c|}{$\begin{array}{c}28-50 \\
34.75 \pm 6.97\end{array}$} & \multicolumn{2}{|c|}{$\begin{array}{c}27-50 \\
33.60 \pm 9.4 \\
0\end{array}$} & \multicolumn{2}{|c|}{$\begin{array}{c}29-38 \\
32.25 \pm 4.03\end{array}$} & \multicolumn{2}{|c|}{$\begin{array}{c}26-56 \\
37.63 \pm 9.8 \\
5\end{array}$} \\
\hline \multirow[t]{3}{*}{ Marital status } & Single & 2 & 18.2 & 0 & 0.0 & 2 & 40.0 & 1 & 25.0 & 5 & 16.7 \\
\hline & Married & 9 & 81.8 & 9 & 90.0 & 3 & 60.0 & 3 & 75.0 & 24 & 80.0 \\
\hline & Widower & 0 & 0.0 & 1 & 10.0 & 0 & 0.0 & 0 & 0.0 & 1 & 3.3 \\
\hline \multirow{4}{*}{$\begin{array}{l}\text { Level of } \\
\text { Education }\end{array}$} & SNS Diploma• & 5 & 45.5 & 9 & 90.0 & 1 & 20.0 & 1 & 25.0 & 16 & 53.3 \\
\hline & THI Diploma•• & 1 & 9.1 & 0 & 0.0 & 0 & 0.0 & 1 & 25.0 & 2 & 6.7 \\
\hline & BSc Nursing ••• & 5 & 45.5 & 1 & 10.0 & 4 & 80.0 & 1 & 25.0 & 11 & 36.7 \\
\hline & $\begin{array}{l}\text { M.Sc. } \\
\text { Nursing.... }\end{array}$ & 0 & 0.0 & 0 & 0.0 & 0 & 0.0 & 1 & 25.0 & 1 & 3.3 \\
\hline
\end{tabular}

-SNS Diploma: Secondary Nursing School Diploma. • THI Diploma: Technical Health Institute Diploma. $\cdots$ BSc Nursing: Bachelor of Science in Nursing. $\cdots$ M.Sc. Master Degree in nursing.

Table (2): Occupational characteristics of head nurses in the study setting (n=30).

\begin{tabular}{|c|c|c|c|c|c|c|c|c|c|c|c|}
\hline \multirow{3}{*}{\multicolumn{2}{|c|}{$\begin{array}{l}\text { Occupational } \\
\text { characteristics }\end{array}$}} & \multicolumn{8}{|c|}{ Hospitals Name } & \multirow{2}{*}{\multicolumn{2}{|c|}{$\begin{array}{l}\text { Total } \\
\mathbf{n}=\mathbf{3 0}\end{array}$}} \\
\hline & & \multicolumn{2}{|c|}{$\begin{array}{l}\text { PSH } \\
\mathbf{n}=11\end{array}$} & \multicolumn{2}{|c|}{$\begin{array}{c}\text { PFH } \\
\mathbf{n}=10\end{array}$} & \multicolumn{2}{|c|}{$\begin{array}{c}\mathbf{E Z H} \\
\mathbf{n}=5\end{array}$} & \multicolumn{2}{|c|}{$\begin{array}{c}\text { ENH } \\
\mathbf{n}=4\end{array}$} & & \\
\hline & & NO & $\%$ & NO & $\%$ & NO & $\%$ & NO & $\%$ & NO & $\%$ \\
\hline \multirow[t]{6}{*}{ Units Name } & Medicine & 2 & 18.2 & 3 & 30.0 & $\mathbf{1}$ & 20.0 & $\mathrm{O}$ & O.O & 6 & 20.0 \\
\hline & Surgery & 2 & 18.2 & 2 & 20.0 & 1 & 20.0 & $\mathrm{O}$ & O.O & 5 & 16.7 \\
\hline & $\begin{array}{l}\text { Critical } \\
\text { care }\end{array}$ & 2 & 18.2 & 2 & 20.0 & 2 & 40.0 & 2 & 50.0 & 8 & 26.7 \\
\hline & $\begin{array}{l}\text { Emergency } \\
\text { \& accident }\end{array}$ & 3 & 27.2 & 1 & 10.0 & 1 & 20.0 & 1 & 25.0 & 6 & 20.0 \\
\hline & $\begin{array}{l}\text { Obs \& } \\
\text { Gyne }\end{array}$ & 2 & 18.2 & $\mathbf{1}$ & 10.0 & $\mathrm{O}$ & O.O & $\mathrm{O}$ & O.O & 3 & 10.0 \\
\hline & Pediatric & $\mathrm{O}$ & O.O & 1 & 10.0 & $\mathrm{O}$ & O.O & 1 & 25.0 & 2 & 6.7 \\
\hline \multirow{4}{*}{$\begin{array}{l}\text { Level of } \\
\text { experience } \\
\text { in the } \\
\text { nursing } \\
\text { field (years) }\end{array}$} & $<5 y$ & 2 & 18.2 & $\mathrm{O}$ & O.O & 3 & 60.0 & $\mathrm{O}$ & O.O & 5 & 16.7 \\
\hline & $5-y$ & 5 & 45.5 & 2 & 20.0 & $\mathbf{1}$ & 20.0 & 4 & 100 & 12 & 40.0 \\
\hline & $25-y$ & 1 & 9.1 & 4 & 40.0 & 1 & 20.0 & $\mathrm{O}$ & O.O & 6 & 20.0 \\
\hline & $35+y$ & $\mathrm{O}$ & O.O & 2 & 20.0 & $\mathrm{O}$ & O.O & $\mathrm{O}$ & O.O & 2 & 6.7 \\
\hline $\begin{array}{l}\text { Min - max } \\
\text { Mean } \pm \text { SD }\end{array}$ & & \multicolumn{2}{|c|}{$\begin{array}{l}8-36 \\
24.18 \pm 10.2 \\
6\end{array}$} & \multicolumn{2}{|c|}{$\begin{array}{l}3-30 \\
15.10 \pm 11.48\end{array}$} & \multicolumn{2}{|c|}{$\begin{array}{l}2-32 \\
10.20 \pm 12.5 \\
8\end{array}$} & \multicolumn{2}{|c|}{$\begin{array}{l}6-10 \\
7.50 \pm 1.73\end{array}$} & \multicolumn{2}{|c|}{$\begin{array}{l}2-36 \\
16.60 \pm 11 \\
85\end{array}$} \\
\hline \multirow{3}{*}{$\begin{array}{l}\text { Level of } \\
\text { experience } \\
\text { in current } \\
\text { position } \\
\text { (years) }\end{array}$} & $<10$ y & 8 & 72.7 & 4 & 40.0 & 5 & 100 & 3 & 75.0 & 20 & 66.7 \\
\hline & $10-y$ & 2 & 18.2 & 2 & 20.0 & $\mathrm{O}$ & O.O & 1 & 25.0 & 5 & 16.7 \\
\hline & $\mathbf{2 0}+\mathbf{y}$ & 1 & 9.1 & 4 & 40.0 & $\mathrm{O}$ & O.O & $\mathrm{O}$ & O.O & 5 & 16.7 \\
\hline $\begin{array}{l}\text { Min - max } \\
\text { Mean } \pm \text { SD }\end{array}$ & & \multicolumn{2}{|c|}{$\begin{array}{l}3-34 \\
14.55 \pm 9.47\end{array}$} & \multicolumn{2}{|c|}{$\begin{array}{l}3-38 \\
11.80 \pm 10.59\end{array}$} & \multicolumn{2}{|c|}{$\begin{array}{l}2-3 \\
2.60 \pm 0.55\end{array}$} & \multicolumn{2}{|c|}{$\begin{array}{l}6-10 \\
7.50 \pm 1.73\end{array}$} & \multicolumn{2}{|c|}{$\begin{array}{l}2-34 \\
10.70 \pm 9.2 \\
1\end{array}$} \\
\hline
\end{tabular}


Table (3): Head nurses' job stress levels in the study sample. $(\mathrm{N}=30)$

\begin{tabular}{|c|c|c|c|}
\hline \multirow{3}{*}{ Dimensions of job stress } & \multicolumn{3}{|c|}{ Level of job stress } \\
\hline & Low & Moderate & High \\
\hline & $\begin{array}{l}\text { NO } \\
\%\end{array}$ & $\begin{array}{l}\text { NO } \\
\%\end{array}$ & $\begin{array}{l}\text { NO } \\
\%\end{array}$ \\
\hline 1. Work environment stressors & $\begin{array}{c}8 \\
26.6 \\
\end{array}$ & $\begin{array}{c}7 \\
23.3\end{array}$ & $\begin{array}{l}15 \\
50.0\end{array}$ \\
\hline 2. Workload stressors & $\begin{array}{c}15 \\
50.0\end{array}$ & $\begin{array}{c}9 \\
30.0\end{array}$ & $\begin{array}{c}6 \\
20.0\end{array}$ \\
\hline $\begin{array}{l}\text { 3. Work duties and responsibilities } \\
\text { stressors }\end{array}$ & $\begin{array}{c}14 \\
46.6\end{array}$ & $\begin{array}{c}10 \\
33.3\end{array}$ & $\begin{array}{c}6 \\
20.0\end{array}$ \\
\hline 4.Lack of organization support stressors & $\begin{array}{c}2 \\
6.6\end{array}$ & $\begin{array}{c}8 \\
26.6 \\
\end{array}$ & $\begin{array}{c}20 \\
66.6\end{array}$ \\
\hline $\begin{array}{l}\text { 5.Head nurses' capabilities for meeting } \\
\text { work demand stressors }\end{array}$ & $\begin{array}{c}19 \\
63.6\end{array}$ & $\begin{array}{c}7 \\
23.3 \\
\end{array}$ & $\begin{array}{c}4 \\
13.3 \\
\end{array}$ \\
\hline 6. Work and education stressors & $\begin{array}{c}4 \\
13.3 \\
\end{array}$ & $\begin{array}{c}9 \\
30.0\end{array}$ & $\begin{array}{c}17 \\
56.6\end{array}$ \\
\hline $\begin{array}{l}\text { 7. Relations between physician \& head } \\
\text { nurses stressors }\end{array}$ & $\begin{array}{c}12 \\
40.0\end{array}$ & $\begin{array}{c}8 \\
26.6\end{array}$ & $\begin{array}{c}10 \\
33.3\end{array}$ \\
\hline 8.Staff nurses stressors & $\begin{array}{ll}3 \\
10.0\end{array}$ & $\begin{array}{c}7 \\
23.3\end{array}$ & $\begin{array}{c}20 \\
66.6\end{array}$ \\
\hline 9.Patients suffering \& death stressors & $\begin{array}{c}13 \\
43.3\end{array}$ & $\begin{array}{c}13 \\
43.3\end{array}$ & $\begin{array}{c}4 \\
13.3\end{array}$ \\
\hline 10.Material stressors & $\begin{array}{c}8 \\
26.6\end{array}$ & $\begin{array}{c}2 \\
6.6\end{array}$ & $\begin{array}{c}20 \\
66.6\end{array}$ \\
\hline $\begin{array}{l}\text { 11. Work satisfaction in addition to } \\
\text { achievement and promotion stressors. }\end{array}$ & $\begin{array}{c}4 \\
13.3 \\
\end{array}$ & $\begin{array}{c}6 \\
20.0 \\
\end{array}$ & $\begin{array}{c}20 \\
66.6 \\
\end{array}$ \\
\hline $\begin{array}{l}\text { Total scores of job stress: } \\
\text { High job stress }\end{array}$ & & $\begin{array}{l}18 \\
60.0\end{array}$ & \\
\hline Moderate job stress & & $\begin{array}{c}4 \\
13.3 \\
\end{array}$ & \\
\hline Low job stress & & $\begin{array}{c}8 \\
26.7\end{array}$ & \\
\hline
\end{tabular}


Table (4): Head nurses' job performance levels in the study sample. (N=30)

\begin{tabular}{|c|c|c|c|c|}
\hline \multirow{3}{*}{ Dimensions of job performance } & \multicolumn{4}{|c|}{ Job performance level } \\
\hline & \multicolumn{2}{|c|}{ Well $\geq 68$} & \multicolumn{2}{|c|}{ Poor $<68$} \\
\hline & NO & $\%$ & NO & $\%$ \\
\hline $\begin{array}{l}\text { I -Work hours habits } \\
\text { dimensions } \\
\text { A-Work hours compliance / } \\
\text { attendance }\end{array}$ & 9 & 30.0 & 21 & 70.0 \\
\hline $\begin{array}{l}\text { II -Work dimensions: } \\
\text { A-Quality and quantity of } \\
\text { work } \\
\text { B- Patients service } \\
\text { C-Job knowledge and skills } \\
\text { D-Workload management } \\
\text { E- Safety / health }\end{array}$ & $\begin{array}{c}6 \\
6 \\
5 \\
5 \\
2 \\
11\end{array}$ & $\begin{array}{c}20.0 \\
20.0 \\
16.7 \\
16.7 \\
6.7 \\
36.7\end{array}$ & $\begin{array}{l}24 \\
24 \\
25 \\
25 \\
28 \\
19\end{array}$ & $\begin{array}{l}80.0 \\
80.0 \\
83.3 \\
83.3 \\
93.3 \\
63.3\end{array}$ \\
\hline $\begin{array}{l}\text { III -Leadership / supervisory } \\
\text { dimensions: } \\
\text { A-Leadership / Delegation } \\
\text { B-Training / orientation } \\
\text { C- Attitude and Mood }\end{array}$ & $\begin{array}{c}0 \\
23 \\
6 \\
0\end{array}$ & $\begin{array}{c}0.0 \\
76.7 \\
20.0 \\
0.0\end{array}$ & $\begin{array}{c}30 \\
7 \\
24 \\
30\end{array}$ & $\begin{array}{c}100 \\
23.3 \\
80.0 \\
100\end{array}$ \\
\hline $\begin{array}{l}\text { IV -Employments dimension: } \\
\text { A- Adaptability and } \\
\quad \text { cooperation } \\
\text { B- Communications } \\
\text { C-Interpersonal skills } \\
\text { D- Initiative }\end{array}$ & $\begin{array}{c}8 \\
11 \\
9 \\
7 \\
6\end{array}$ & $\begin{array}{l}26.7 \\
36.7 \\
30.0 \\
23.3 \\
20.0\end{array}$ & $\begin{array}{l}22 \\
19 \\
21 \\
23 \\
24\end{array}$ & $\begin{array}{l}73.3 \\
63.3 \\
70.0 \\
76.7 \\
80.0\end{array}$ \\
\hline $\begin{array}{l}\text { Total scores of job performance: } \\
\text { Well job performance }(\geq 68 \%)\end{array}$ & & & & \\
\hline Poor job performance $(<68 \%)$ & & & & \\
\hline
\end{tabular}


Table (5): Correlations matrix between head nurses' work stress and job performance scores in study sample. $(n=30)$.

\begin{tabular}{||l|l|l||}
\hline \multirow{2}{*}{ Variables } & \multicolumn{2}{|l|}{ job stress score } \\
\cline { 2 - 4 } & R-value & p-value \\
\hline $\begin{array}{l}\text { Job } \\
\text { performance }\end{array}$ & .222 & 238 \\
\hline
\end{tabular}

* Correlation is significant at the 0.05 level.

And head nurses' level of job stress.

\section{DISCUSSION :}

Job stress, in today's world problems, in a variety of disease or physical or mental disability organizations leads to low performance and high cost for organizations. Therefore, the purpose of the study was to investigate the stress performance relationship. The literature reinforced the need for the present study by indicating that nursing is one of the highest stressful professions and by showing the lack of consistency of findings regarding the impact of job stress on job performance. Many studies showed that intense job-related demands are a major source of stress among managers and often have significant negative effects on job performance and personal well-being (Sullivan \& Decker, 2005; Creasia \& Parker, 2007).

Regarding assessment of job stress levels the results showed that the highest percentage of head nurses had experienced high level of job stress. Data showed that, high level of head nurses' job stress resulted from work environment, lack of organization support, understaffing, material/equipment, and work satisfaction in addition to achievement and promotion. These findings are consistent with Hamouda (2006) who found that the majority of head nurses had experienced high levels of stress. On the contrary, Vickie and Melinda (1996) found that half of the respondents sample had experienced low levels of stress.

Concerning the source of job stress, the current study indicated that the lack of organization support stressors was notably the most common factor contributing to work stress among head nurses working in the four hospitals Port-Said, Port-Fouad, El-Zohoor, and El-Naser hospital. The head nurses really suffer from lack of support from hospital management and direct leader, they felt lack of concern for their complaints, and felt lack of confidence in their executive staff especially when the unit executives take decisions alone, and they complained of lack substantial reward and lack of opportunities for development. These findings are consistent with those of Taylor et al., (1999); Clegg (2000); Shehata (2008) who stated that managers were the main distal cause of stress and they had a direct influence on increasing 
nurses' stress. Similarly, Tyson et al., (2002) concluded that the lack of organizational support and involvement was the major source of stress reported by their sample of hospital nurses in Ontario. Also, Peter and Charles (1998) found that job pressure and lack of organization support are major dimensions of occupational stress in a variety of work settings. The result of the current study contradicts those of Mcvicar (2003) and Makanjce (2004) who found that the most common sources of occupational stress were related to workload and task overload.

Concerning staff nurses' stressor dimension, the current study showed that the highest percentage of head nurses had experienced high levels of work stress related to staff nurses', stressor dimension was the most common work stress-contributing factor among head nurses. The fact is that those nurses showed un-responsible personality as they arrived late to their shifts. This behaviour contributes to quantitative and qualitative shortage of nurses. Working without enough ancillary personnel always leads to excessive work overload and minimal vacations. The result of present study was consistent with Callaghen et al., (2000) who revealed that understaffing and work overload are the major stressor factors reported by nurses sample, and inadequate staffing levels were the highest stressor for nurses working in ICUs. In this regard, Healy and Mckay (2000) concluded that lack of human resources potentially had effects on patients and contributed to crisis in nurses' morale. Also, Tomey (2009) asserted that mandatory overtime and decreased staffing ratios have increased the nurses' stress.

In addition, the present study indicated that the highest percentage of head nurses had experienced high levels of work stress related to work environment stress among the head nurses in all four hospitals whereas physical work environment could be attributed to the elements in the work environment that are stressful for example, noise level, malfunctioning or inefficient or shortage of equipment, working in closed place, hearing sounds of patient moaning, numerous machines around nurses, working in artificial light or poor lighting and nurses are exposed to see naked patients. All these were environmental stressing factors having a profound effect on nurses and head nurses, which can decrease their efficiency and cause fatigue, stress, decrease productivity. The results are consistent with previous studies that identified the work place as an occupational stress (Healy and Mckay, 2000). Also, Callaghan et al., (2000) and Aamodt (2007) reported that the major source of stress was related to poor working environment. Similar finding was reported by EL-Shaer (2009) who found that ICU working environment is a stress-contributing factor for nurses working in different ICUs at Mansoura University hospitals. 
Regarding the assessment of the head nurses' job performance, the current study shows that the majority of head nurses had poor job performance. This finding might be attributed to that they were not trained in management as less than a quarter of the studied head nurses have attended management training program. So, they need to have training to improve their job performance. In addition, the majority of them had diploma of nursing school where the nursing diploma curriculum did not include job performance as a basic skill of management in nursing education. This goes in line with Aamodt (2007) who asserted that leadership performance can be improved by teaching leaders to become better.

The findings of this study indicated no significant correlation between job performance and head nurses' level of work stress. This result was contrary with Westman and Eden (1996) who used a correlational design to investigate the relationship between stress resulting from excessive demands and performance among cadets. Their findings indicated a negative linear relationship between stress and job performance. Similarly, Leveck and Jones (1996), using correlational designs, found that high job stress among nurses correlated with low job performance. Kazmi et al., (2008), indicated that there is an inverse relationship between job stress and job performance hence, high job stress in house officers results in low job performance. In addition, the World Health Organization, (2005) and International Labour Organization, (2001) supported this study.

In addition, this result is supported by Azizollah et al., (2013), using correlational descriptive designs they found negative correlation between job stress and performance. Jehangir et al., (2011), revealed that, job stress was negatively correlated with job performance. In this regard, Certo (2003) and Muse et al (2003) reported on the relationship between job stress and job performance. On the job, employees tend to perform best when they are experiencing a moderate degree of stress. However, too much stress brings problems, especially when the sources of stress are negative (e.g., a critical manager or unsafe working conditions).

Furthermore, Certo (2003), noticed that the relationship between work stress and job performance can be either positive or negative. Similarly, El-Sayed (1997) clarified that stress can be either helpful or harmful to the job, depending upon its amount. When there is no stress, job challenges are absent and performance tends to be low. As stress increases, performance tends to increase, because stress helps a person call up resources to meet job requirement. It is a health stimulus that encourages employees to respond to challenges. If stress becomes too great, performance tends to decline, because employee loses the ability to cope with stress and becomes unable to make decisions and erratic in behavior. 


\section{CONCLUSION:}

\section{Based on the results of the present study, it can be concluded that:}

the head nurses working in all patient care units at four hospitals had experienced high level of job stress and job performance was poor in all dimensions. Finally, this study indicates that there was no statistically significant correlation between job stress levels and job performance of head nurses.

\section{RECOMMENDATIONS:}

\section{Based on the results of this study, the following recommendations are suggested:}

Provide counseling office with a trained staff, support groups, and team building activities for the head nurses to counteract the undesirable levels of work stress. Great attention of nursing and medical executives to plan for conducting collaborative medical and nursing workshops to break down barriers of communication, and promote collaboration between physicians, heads nurses, and staff nurses. Hospital administrators might initiate stress management program inside the hospital for all employees, in order to limit the stressful situations, overcome crisis and improve nursing staff performance. Continuous and regular inservice educational programs and other development activities such as conferences, seminars, and workshops to achieve the application of work stress management and other managerial skills should be conducted to improve the head nurses' competency level.

\section{REFERENCES :}

Aamodt, M., (2007). Industrial / organizational psychology: An applied approach. $5^{\text {th }}$ ed., United States: Thomson Wands worth. Co., 227-229, 512-513, 529.

Abdelrazek, F., (2000). Study of absenteeism and factors contributing to it among head and staff nurses .Unpublished master thesis in nursing administration. Suez Canal University. Fac. $\mathrm{Ng}$, Egypt.

Al-khasawneh, A.L.; Futa, S.M., (2013). The Relationship between Job Stress and Nurses Performance in the Jordanian Hospitals: A Case Study in King Abdullah the Founder Hospital. Asian Journal of Business Management 5(2): 267-275.

Aslam, H.D., (2011). Performance evaluation of teachers in universities: Contemporary issues and challenges in Pakistan. International conference presented at national conference on teaching, learning and change in higher education in Pakistan, Islamabad: Pakistan: 339-362.

Azizollah, A.; Zaman, A.; Khaled, O.; Razieh, J., (2013). The relationship between job stress and performance among the hospitals nurses. World of Sciences Journal;(02): 181-188. Retrieved from www.engineerspress.com 
Callaghan, P.; Ann, S.; Wyatt, P., (2000). Factors related to stress and coping among Chinese nurses in Hong Kong. Journal of Advanced Nursing; 31 (6): 1518-1527.

Casio, W.F., (2013). Managing Human Resources: Productivity, Quality of Work Life, Profits. 9th Ed., McGraw-Hill, Irwin, New York, pp: 44.

Certo, S.C., (2003). Supervision: Concepts and skill building. $4^{\text {th }}$ ed., Avenue of the Americas: New York, McGraw-Hill/Irwin co., 67-73, 282-283, 354-367.

Clegg, B., (2000). Instant stress management. Dictionary of Education-A Practical Approach. New Delhi: Kanishka Publishers: 92-96.

Creasia, J.; Parker, B., (2007). Conceptual Foundations: The Bridge to Professional Nursing Practice. 4th ed. United States of America: Mosby Elsevier Co., 360-445.

Crosby, R.A.; DiClemente, R.J.; Salazar, L.F., (2006). Research methods in health promotion. San Francisco: John Wiley \& Sons, Inc: 22-29.

El-Sayed, K., (1997).The relationship between perceived role conflict and role ambiguity with stress level among new baccalaureate nursing graduates and interns in Tanta university hospital. Unpublished master thesis in nursing administration. Alexandria University. Fac. Ng. Egypt.

El-Shaer, A., (2009). Organizational structure features influence on occupational stress for intensive care nurses and strategies for dealing with stress. Unpublished doctoral thesis in nursing administration. Mansoura University. Fac. Ng. Egypt.

El-Sherif, Z., (1998). Perceived sources of stress and reactions to stressful situations among nurses working in psychiatric hospitals. Unpublished thesis, Master degree of psychiatric nursing: Faculty of Nursing, Alexandria University.

Grat-Toft, P.; Anderson, J. (1981). The nursing stress scale: Development of an instrument. Journal of behavioral assessment.3, 11-23.

Hamouda, G., (2006). The effect of time management training program for head nurses on their performance, stress and job satisfaction. Unpublished doctorate thesis in nursing administration. Alexandria University, Fac. Ng. Egypt.

Healy, C.; Mckay, M., (2000). Nursing stress: The effects of coping strategies and job satisfaction in a sample of Australian nurses. JONA, 31 (3): 681-688.

Herbett, H.; Timothy, J.; Robett, H., (2000). Staffing Organizations. 3rd ed., Burr Ridge, II; McGraw Hill/ Irwin, 198. 
Hermina, M.; Nabawy, Z.; Baddar, F., (2003). Head nurses perception and performance of the elements promoting effective team work. Bulletin Alexandria Scientific Nursing Journal, 2(2): 85- 101.

International Labour Organization (ILO) (1998). Encyclopaedia of Occupational Health and Safety. $4^{\text {th }}$ ed., Geneva, Switzerland: International Labour Office.

Jaramillo, F., J.P. Mulki and J.S. Boles, (2011). Workplace stressors, job attitude and job behaviors: Is interpersonal conflict the missing link? J. Pers. Sell. Sales Manag; 31(3): 339356.

Jehangir, M.; Kareem, N.; Khan, A.; Jan, M.T.; Soherwardi, S., (2011). Effects of job stress on job performance \& job satisfaction. Interdisciplinary journal of contemporary research in business. Institute of Interdisciplinary Business, (3):7, 453-465.

Kazmi, R.; Amjad, S.; Khan, D., (2008). Occupational stress and its effect on job performance a case study of medical house officers of districts of Abbottabad, journal Ayub Med Coll Abbottabad, 20(3) http://www.ayubmed.edu.pk/JAMC/PAST/20-3/Rubina.pdf

Kreitner, R. and A. Kinicki, (2010). Organizational Behavior. 9th Edn., McGraw Hill Irwin, Boston, pp: 556-558.

Larrabee, J.; Ostrow, C.; Withrow, M.; Janney, M.; Hobbs, G.; Burant, C., (2004). Predictors of patient satisfaction with inpatient hospital nursing care. Research in Nursing and Health;27: 254-268.

Leveck, M.; Jones, C., (1996). The nursing practice environment, staff retention, and quality of care. Research in Nursing and Health; 19:331-43.

Makanje C., (2004). The Effect of Occupational Stress and Organizational Commitment on Diagnostic Imaging Radiographers in Rendering Quality Service. Unpublished Msc N, Thesis in Radiographic sciences, Faculty of Health Sciences, University of Pretoria.

Mcvicar, A., (2003). Work place stress in nursing: a literature review. Journal of Advanced Nursing; 44 (6): 633-642.

Muse, K.A; Harris, S.G.; Field, H.S., (2003). Has the inverted u theory of stress and job performance had a fair test? Human Performance; 16(4): 349-364.

Owolabi1, A.O., M.O. Owolabi, A.D. OlaOlorun and A. Olofin, (2012). Work-related stress perception and hypertension amongst health workers of a mission hospital in Oyo State, South-western Nigeria. Afr. J. Primary Health Care Family Med; 4: 17.

Robbins, S.P.; Judge, T. A., (2009). Organizational behavior, $5^{\text {th }}$ ed., United States: New Jersey, Pearson Prentice hall Inc., 24: 678. 
Rue, L.W. and L.L. Byars, (2007). Management: Skills and Application. 12th Ed, McGraw Hill Irwin, Boston, pp: 348-350.

Salami, A.O., R.M. Ojokuku and O.A. Ilesanmi, (2010). Impact of job stress on managers' performance. Eur J Sci Res; 45(2): 249-260.

Sekaran, U., (2004). Research Methods for Business: A Skill-Building Approach. 4th Ed , John Wiley and Sons, Inc., Singapore.

Shash, H., (2006). The relationship between job stress, job performance, and social support among nurses at Alexandria main university hospital. Unpublished master thesis in nursing administration, Alexandria University, Fac. Ng. Egypt.

Shehata, R., (2008). Organizational culture versus occupational stress among staff nurses at Mansoura university hospital. Master degree; Faculty of Nursing, Ain Shams University. 98118.

State of Missouri Office of Administration Division of Personnel (SMOADP). (2010). Perform writing performance objectives for job components: A brief tutorial. Retrieved May 26, 2010.from http:// www.perform.mo.gov .

Steers, R.; Black, J., (1994). Organizational behavior. $5^{\text {th }}$ ed. United States of America: Harper Collins College publisher, 611-12.

Sullivan, E.; Decker, P., (2005). Effective leadership \& management in nursing, leading and managing. $6^{\text {th }}$ ed., United States: New Jersey co., 283-284.

Taylor, D.; Whit, B.; Muncer, S., (1999). Nurses cognitive structural models of work-based stress. Journal of advanced nursing;29 (4): 974-983.

Tomey, A.M., (2009). Guide to nursing management and leadership, $8^{\text {th }}$ ed., Canada, Elsevier, 34.

Tuten, T, Neidermeyer, $\boldsymbol{P}$., (2004). Performance, satisfaction and turnover in call centers the effects of stress and optimism. Journal of Business Research; 57:26-34.

Tyson, P.D.; Pongruengphant, R.; Aggarwal, B., (2002). Coping with organizational stress among hospital nurses in southern Ontario. International Journal of Nursing Studies 39: 453459. Retrieved from www.elsevier.com/locate/1jnurstu

Ugur, S., A.M. Acuner, B. Göktaş and B. Senoğlu, (2007). Effects of physical environment on the stress levels of hemodialysis nurses in Ankara Turkey. J Med Syst; 31: 283-287.

University of Chicago Human Resources (UOCHR). (2005). Job performance checklist, Retrieved May 26, 2010.from http:// www.hr.uchicago.edu/ train /.../ pdfs / job \%20 performance $\% 20$ checklist pdf. 
Vickie, L.; Melinda H., (1996). Occupational Stress and Organizational Commitment in Nurse Administrators. JONA; 26 (5): 21-28.

Westman, M.; Eden, D., (1996). The inverted-U relationship between stress and performance: A field study. Work and Stress;s 10:165-73.

Wilton, N., (2011). An Introduction to Human Resource Management. SAGE, Los Angeles, pp: 113-419.

World Health Organization. (2005). Mental health and working life. WHO European Ministerial conference on mental health: Facing the challenges, building solutions. Retrieved June 19, 2007, from www.euro.who.int/document/mnh/ebriefo6.pdf. 


\section{العلاقة بين ضغوط العمل و الأداء الوظيفي لرئيسات وحدات التمريض}

$$
\text { م.م غادة مسعد محمد الغبور / د فتحية عبد الرازق عفيفى / أ.د ماجدة طه كمال الدين فهمي }
$$

مدرس مساعد إدارة التهريض -كلية التصريض-جامعة بورسعبد ـمدرس إدارة التصريض-كلية التصريض-جامعة قناة السوبيس ـ أستاذ الطب النفسي-كلية الطب-جامعة قناة السويب ـأستاذ إدارة التصريض-كلية التصريض-جامعة دمنهور

\section{الخلاصة}

إن مهنة التمريض تمثل جزءا كبير امن الرعاية الصحية. إنها جزء حيوي ومهم في جودة رعاية المرضى ونجاح أي نظام

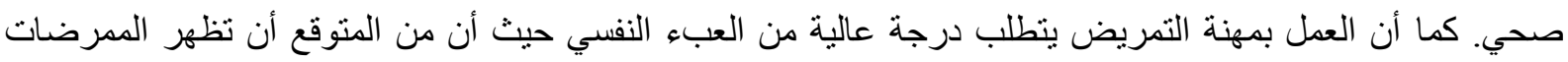
مشاعر الاهتمام بالمرضى و التفهم و التعاطف معهم مع التحكم في مشاعر هن الخاصة.أجريت هذه الدر اسة بأربع مستشفيات

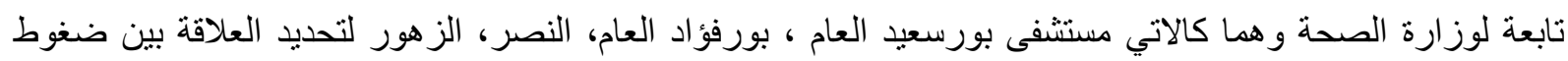
العمل و الأداء الوظيفي لرئيسات وحدات التمريض، من أجل إيفاء هذا الهدف اثتتملت عينة البحث على 30 رئيسة لوحدات التمريض، وقد تم تجميع البيانات عن طريق أداتين: الاداة الاولى مكونة من جزئيين، الجزء الأول يشتمل على استبيان للمقابلة الثخصية : الخصائص الثخصية و الوظيفية لرئيسات وحدات التمريض، الجزء الثاني يشنمل على استمارة

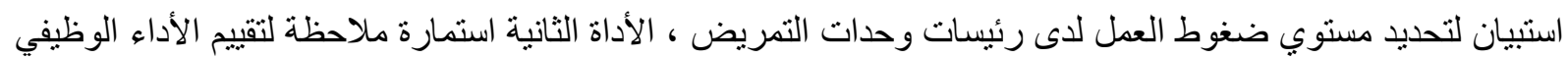
لرئيسات وحدات التمريض أثناء العمل، و أظهرت النتائج تحسنا ملحوظا في مستوى ضغوط العمل ، الأداء الوظيفي، معلومات وممارسات رئيسات وحدات التمريض تجاه ضغوط العمل و استر اتيجيات التعامل معها بعد تتفيذ البرنامج مباشرة

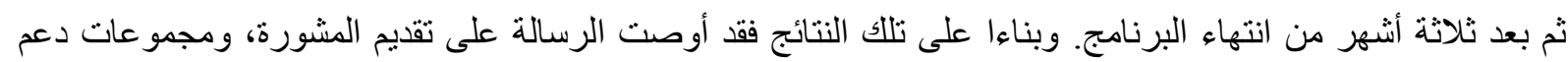
لرئيسات وحدات التمريض إلى مواجهة المستويات الغير مرغوب فيها من الضغط النفسي وتعزيز الأداء الجيد. الى جانب ذللك، مديري المستشفيات عليهم بدء تنفيذ مشروع إدارة الضغوط داخل المستشفى لجميع الموظفين، وينبغي أن تدرج رئيسات وحدات التمريض، وذللك للحد من حالات التونر، و السلوكيات غير المرغوب فيها، و التغلب على إدارة الأزمات

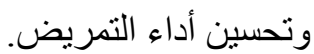

الكلمات الاسترشاديه : ضغوط العمل - الأداء الوظيفي - رئيسات وحدات التمريض 